\title{
Late-Study Areas: A Means Of Extending Library Hours
}

In a survey of the late-evening service provided by 169 academic libraries, it was found that late-night study areas were being used in thirty libraries as a means of extending hours of opening. Most of these areas were open for one to three hours after the library's normal closing hour, with only nine remaining open all night. Room counts for the twenty-four-hour study area at the University of Denver show use of the area to be light after 2:00 a.m.

S

S. HOURs seems to be one of the few characteristics of that group remaining constant from one generation to the next. One of the more economical courses of action available to librarians facing this continuing student pressure for longer hours is the late-evening study area, a section of the library kept open on a long hour or twenty-four hour basis while the remainder of the library follows its regular schedule.

In order to determine the popularity of the late-study concept, a questionnaire was circulated to a random sampling of 196 academic libraries serving both public and private four-year institutions inquiring into the nature of the late-evening service provided. ${ }^{1}$

One hundred sixty-nine questionnaires were returned. The average library in the sample group served a student population of 10,686 with a collection of 531,651 volumes. There were 22.2 professionals and 37.3 clericals on the staff and 56 percent of its total 1971 budget of $\$ 986,174$ was expended on salaries and wages. The circulation of

$M r$. Beeler is a reference librarian at the University of Denver, Colorado.

this average library was 214,534 volumes per year. The largest library among those responding held a collection of $4,200,635$ volumes and the smallest, 21,569 volumes.

\section{Hours of Opening}

The average response to a question concerning total weekly hours of operation was computed at 90.3 hours, with 114 hours and 56 hours being the maximum and minimum figures. Eighty-seven, or 52 percent, of the replies indicated that minor extensions in hours were routinely made to accommodate increased use of the library during examination periods. Closing times, to the nearest half hour, were as follows:

Closing Time

8:00 p.m.

9:00 p.m.

9:30 p.m.

10:00 p.m.

10:30 p.m.

11:00 p.m.

11:30 p.m.

12:00 midnight

1:00 a.m.

2:00 a.m.

Total

These findings are comparable to
No. of Libraries

$\begin{array}{r}1 \\ 3 \\ 1 \\ 35 \\ 14 \\ 55 \\ 3 \\ 53 \\ 3 \\ 1 \\ \hline 169\end{array}$
$\frac{1}{169}$ 
those of Cain's 1969 survey of thirtysix state and private universities which reported an average of 94.3 weekly hours of operation with 11:00 p.m. being the most common closing time. ${ }^{2}$

In a major portion of the libraries surveyed, professional librarians were on duty in public service areas until 10:00 p.m. In one instance, however, professional coverage was provided until 1:00 a.m.

\section{Latest Hour of}

Professional

Coverage

5:00 p.m.

8:30 p.m.

9:00 p.m.

9:30 p.m.

10:00 p.m.

10:30 p.m.

11:00 p.m.

12:00 midnight

12:30 a.m.

1:00 a.m.

not reporting

Total

No. of Libraries

20

1

11

7

87

8

17

6

1

1

10

169

\section{Late Study Areas}

Thirty libraries, or 18 percent of the return, reported having some form of late-study facility.

Eleven of these thirty late-study areas were operated for one to two hours after the library's closing hour; eight were open for three to four hours following closing; and nine were operated on an around the clock basis, remaining open from the time of the library's closing until its opening on the following day. Although not uniformly reported, in seven cases the late-study rooms were operated on a Sunday through Thursday schedule, and in two cases the studies were open only on weekends.

As can be seen from Table 1, supervision or monitoring of the late-study rooms was reported as being generally light. Curiously, when staffing was con-

sidered in conjunction with hours of operation it was found that monitoring was lightest in the eight twenty-fourhour study areas, with five of these areas being unattended. Each of these five libraries reported having experienced no problem with vandals or vagrants abusing the twenty-four-hour unattended areas. A total of nine, or 30 percent, of the late-study areas reported were unstaffed.

In twenty of the late studies described, patrons had no access to the library's collection while using the study area after the normal closing hour, with the possible exception of small paperback reference and recreational collections. In ten cases, however, access was allowed to major areas of the library, such as the reserve collection, or all the materials housed on a particular floor. In each case of this nature, library staff were required to supervise the study area while in operation.

Professional reaction to the question of longer hours is widely divergent. Fourteen librarians indicated that experiments with extended hours (one case involving a late study) had yielded unimpressive results and had been discontinued. Several others voiced strong doubts as to the validity of student demands for longer hours. As one librarian remarked, "I will personally open the library for any student who can show me a schedule allowing no time for study during library hours."

In contrast, comments from libraries having late-study areas were enthusiastic and usually couched in terms of how successful the area had been. Although two librarians indicated that their study areas were heavily used only during exam periods, most reported that the areas were justified and had "not been the trouble we anticipated." A library which two years ago began to operate a late-study area open until 3:00 a.m. Sunday through Thursday indicated that this action had "stopped all requests for 
TABLE 1

LATE-STUdY AREAS

\begin{tabular}{|c|c|c|c|}
\hline Institution & Supervision & Hours & $\begin{array}{l}\text { Access to } \\
\text { Collection }\end{array}$ \\
\hline American University & none & 24 hours/day & no \\
\hline California State University & 2 student assistants & 10:00 p.m. $-12: 00$ midnight & yes \\
\hline College of Wooster & 1 student assistant & 5:00 p.m. $-12: 00$ midnight $^{\circ}$ & yes \\
\hline Creighton University & 1 campus security officer & 12:00 midnight-1:00 a.m. & no \\
\hline Dartmouth College & none & 24 hours/day & no \\
\hline Earlham College & none & 11:15 p.m. $-3: 00$ a.m. & no \\
\hline Elmhurst College & nonet & 24 hours/day & not \\
\hline Johns Hopkins University & 1 campus security officer & 24 hours/day & yes \\
\hline Joint University Library & 1 student assistant, 1 campus security officer & 11:00 p.m.-2:00 a.m. & no \\
\hline McKendree College & none & 10:00 p.m.-1:00 a.m. & no \\
\hline Michigan State University & 3 student assistants & 11:00 p.m.-1:00 a.m. & yes \\
\hline Millersville State College & 1 adult clerk, 1 student assistant & 10:00 p.m. $-12: 00$ midnight & yes \\
\hline Mississippi State University & 2 members of fraternity council & 11:00 p.m. $-3: 00$ a.m. & no \\
\hline North Dakota State University & 1 graduate student & 10:30 p.m. $-12: 00$ midnight & no \\
\hline Northern Illinois University & 2 student assistants & $10: 00$ p.m. $-2: 00$ a.m. & yes \\
\hline Occidental College & 1 nonprofessional staff member & 12:00 midnight-2:00 a.m. & no \\
\hline Oregon State University & 1 student assistant & 11:00 p.m. $-1: 00$ a.m. & no \\
\hline Princeton University & none & $12: 00$ midnight $-3: 00$ a.m. & no \\
\hline Purdue University & 2 student assistants & 24 hours/day (finals only) & no \\
\hline Stanford University & none & 12:00 midnight-2:30 a.m. & no \\
\hline Syracuse University & 4 clerks, 1 professional & 11:00 p.m.-1:00 a.m. & yes \\
\hline Tufts University & 1 graduate student & $11: 30$ p.m. $-3: 00$ a.m. & yes \\
\hline University of Denver & 1 student assistant & 24 hours/day & no \\
\hline University of Georgia & 1 student assistant & 12:00 midnight-2:00 a.m. & no \\
\hline University of Maryland, College Park & 1 clerical assistant, 1 security guard & 24 hours/day & no $\ddagger$ \\
\hline $\begin{array}{l}\text { University of Mississippi } \\
\text { University of New Hampshire }\end{array}$ & 2 student assistants & 10:00 p.m.-12:00 midnight & no \\
\hline $\begin{array}{l}\text { University of New Hampshire } \\
\text { University of North Dakota }\end{array}$ & $\begin{array}{l}\text { none } \\
\text { none }\end{array}$ & $\begin{array}{l}24 \text { hours/day } \\
24 \text { hours/day }\end{array}$ & $\begin{array}{l}\text { no } \\
\text { no }\end{array}$ \\
\hline University of South Florida & 3 student assistants & 11:00 p.m.-12:00 midnight & yes \\
\hline University of Southern California & 1 clerk, 2 student assistants & & yes \\
\hline
\end{tabular}

- Friday and Saturday hours only

$\dagger$ Periodic checks by campus security officials

* Access to small recreational or reference collections 
further extension of hours." The belief of some that late-evening study rooms invite abuse and theft of library fixtures is not borne out by the experiences of the libraries responding. As one library operating a twenty-fourhour unattended study area reports: "We've been in our new building over a year and are completely happy about the after-hours study. Nothing (no furniture or books) has disappeared from the study although theft is common in other areas of the campus."

In two cases, librarians indicated that late-study facilities were made available elsewhere on campus and so the library did not feel obliged to duplicate this service.

\section{USE OF THE UNIVERSITY OF Denver's Late-Study Area}

The value of late-study areas can only be discussed in terms of use. Since the opening of the Penrose Library in September of 1972, the University of Denver has operated a late-study area on a twenty-four-hour, Sunday through Thursday basis. The section of the library chosen for this function is the reserve reading area, which is located on the main floor and has a seating capacity of 185 . Drop grills, lowered at midnight when the library closes, prevent access to all library collections. After closing, entry to the late-study area is made by means of a separate side entrance kept locked during regular library hours.

Hourly room count statistics have been kept with the following results: (1) use of the area is heaviest during the latter part of the quarter and dur- ing examination periods; (2) room use drops sharply after 2:00 a.m. and undergoes a minor increase in the hour immediately preceding the library's opening at 8:00 a.m. These points are demonstrated by the following table which indicates the use of the late-study area on the arbitrarily selected dates of January 3, January 30, and March 8, 1973. On the University of Denver calendar, these dates represent the beginning, mid-point, and end of the winter quarter.

\section{Room Count}

Time January 3 January 30 March 8

$\begin{array}{rrrr}12: 45 \text { a.m. } & 11 & 17 & 79 \\ 1: 45 \text { a.m. } & 5 & 12 & 43 \\ 2: 45 \text { a.m. } & 3 & 9 & 29 \\ 3: 45 \text { a.m. } & 1 & 3 & 24 \\ 4: 45 \text { a.m. } & 1 & 0 & 19 \\ 5: 45 \text { a.m. } & 0 & 0 & 20 \\ 6: 45 \text { a.m. } & 0 & 2 & 17 \\ 7: 45 \text { a.m. } & 5 & 5 & 23\end{array}$

The need for longer library hours must certainly be considered in light of the individual campus situation, with particular attention paid to the existence of adequate study space elsewhere on campus. Taking the experience of the University of Denver as representative, however, it appears difficult to justify the twenty-four-hour operation of late-study areas in terms of use, except during those periods immediately preceding and during examinations. At other times an unattended area, open until the early morning hours, would seem preferable. Late-study facilities of this type are currently being operated by the Earlham, McKendree, Princeton, and Stanford libraries.

\section{REFERENCES}

1. Selection of sample was made by random number from the National Center for Educational Statistics, Fall 1971 Compilation of Library Statistics of Colleges and Univer- sities (Washington, D.C.: GPO, 1972).

2. Stith Cain, "Service Hours in Selected Academic Libraries," College and Research Libraries 30:265-66 (May 1969). 